\title{
Effects of nano-scale nutrients supplement on natural productivity of Thalassiosira sp. and growth performance of Pacific white shrimp, Litopenaeus vannamei, reared under intensive conditions using concrete tank culture system
}

\author{
Efek suplementasi nano-nutrien terhadap produktivitas alamiah \\ Thalassiosira sp. dan pertumbuhan udang Litopenaeus vannamei yang \\ dipelihara dalam kondisi intensif menggunakan sistem pemeliharaan \\ bak beton
}

\section{Romi Novriadi', Rifqi Fadhilah², Aldy Eka Wahyudi², Dea Ananda Prayogi², Ilham², Sunil Nanda ${ }^{3,4}$}

\begin{abstract}
${ }^{1}$ Directorate General of Aquaculture, Ministry of Marine Affairs and Fisheries, Republic of Indonesia ${ }^{2}$ Jakarta Technical University of Fisheries, Ministry of Marine Affairs and Fisheries, Republic of Indonesia ${ }^{3}$ Nualgi America, LLc. San Marcos , California 92029, USA

${ }^{4}$ JS Water Energy Life Co 143, Udyog Vihar, Phase 4, Gurgaon, Haryana, 122015, India

*Corresponding author: novriadiromi@yahoo.com
\end{abstract}

(Received September 28, 2020; Accepted October 30, 2020)

\begin{abstract}
The aim of this study was to evaluate the use of unique mixture of nano-nutrient to extent the growth of diatom Thalassiosira sp. and the effect to the water quality, growth performance, and protein composition on the whole body of the Pacific white shrimp Litopenaeus vannamei. There are four treatments with four replicates per treatment with the use of commercial nano-nutrients (Aquaritin Aquaculture or AA) namely: (1) $0.70 \mathrm{mg} / \mathrm{L}$; (2) $0.525 \mathrm{mg} / \mathrm{L}$, (3) $0.35 \mathrm{mg} / \mathrm{L}$, and (4) without any AA application, but included standard application of using urea and NPK fertilizers to enhance the growth of diatom. The use of AA was successful to trigger the growth of Thalassiosira sp. Group of shrimp treated with $0.70 \mathrm{mg} / \mathrm{L}$ had better growth rate. Results of feeding trial indicated that adding AA could also improve the biomass, final mean weight, survival, percentage weight gain, and better feed utilization in terms of FCR. The addition of AA to enhance the growth of Thalassiosira sp. also provides a beneficial impact to the protein composition in whole body of shrimp. Biologically, the protein composition in the whole body of shrimp treated with $0.7 \mathrm{mg} / \mathrm{L}$ was higher. The findings from this study showed that the addition of commercial nano-nutrient could enhance the growth of Thalassiosira sp. and led to better growth of shrimp cultured in concrete tank
\end{abstract}

Key words: Growth, Litopenaeus vannamei, nano-nutrients, protein composition, Thalassiosira sp.

\begin{abstract}
ABSTRAK
Tujuan penelitian yaitu mengevalusi penggunaan campuran unik nano-nutrien untuk meningkatkan pertumbuhan diatom Thalassiosira sp. dan pengaruhnya terhadap kualitas air, laju pertumbuhan, dan komposisi protein pada tubuh udang $L$. vannamei. Terdapat empat perlakuan dan empat ulangan per perlakuan dengan penggunaan nanonutrisi komersial (Aquaritin Aquaculture atau AA) yaitu: (1) $0,70 \mathrm{mg} / \mathrm{L}$; (2) $0,525 \mathrm{mg} / \mathrm{L}$; (3) $0,35 \mathrm{mg} / \mathrm{L}$, dan (4) tanpa pemberian AA, tetapi menggunakan penerapan standar pupuk urea dan NPK untuk pertumbuhan diatom. Penggunaan AA berhasil memicu pertumbuhan Thalassiosira sp. Kelompok udang yang diberi perlakuan $0,70 \mathrm{mg} / \mathrm{L}$ memiliki laju pertumbuhan yang lebih baik. Hasil uji coba pemberian pakan menunjukkan bahwa penambahan AA juga dapat meningkatkan biomassa, bobot rata-rata akhir, kelangsungan hidup, persentase pertambahan bobot dan pemanfaatan pakan yang lebih baik dalam hal FCR. Penambahan AA untuk meningkatkan pertumbuhan Thalassiosira sp. juga memberikan dampak yang menguntungkan bagi komposisi protein di seluruh tubuh udang. Secara biologis komposisi protein di tubuh udang dengan perlakuan $0,70 \mathrm{mg} / \mathrm{L}$ lebih tinggi. Hasil dari kajian ini menunjukkan bahwa penambahan nano-nutrien komersial dapat meningkatkan pertumbuhan Thalassiosira sp. dan mendorong pertumbuhan udang bada sistem budidaya di bak beton.
\end{abstract}

Kata kunci: Komposisi protein, Litopenaeus vannamei, nano-nutrien, pertumbuhan, Thalassiosira sp. 


\section{INTRODUCTION}

Shrimp production system could be considered as the most promising food production sector providing protein-rich supplements for human consumption and constitutes as the valuable internationally traded aquaculture commodity worldwide (Kumar \& Engle, 2016; Samerwong et al., 2018; Lee et al., 2019). Recently, shrimp culture system has changed from extensive, traditional, and small-scale productions to an intensive system that fully support with technology, and large-scale production system to fulfill the market demand (Reis et al., 2020; Bardera et al., 2020; Zulkarnain et al., 2020; Soares et al., 2021). This changed followed by the use of high stocking density ranging from 110-500 shrimp $/ \mathrm{m}^{2}$ for intensive system and $>500$ shrimp $/ \mathrm{m}^{2}$ for supra-intensive farming system (Haslun et al., 2012; Zulkarnain et al., 2020). There are advantages and disadvantages of using (supra) intensive technology. According to Samocha (2019), high stocking density of shrimp in intensive system will lead to greater yields and more efficient in the use of culture environment. However, high inputs of nutrients and limitation on water exchange will create water quality problems that do not always arise in traditional or semi-intensive farming system (Anh et al., 2010; Suantika et al., 2015; Jescovitch et al., 2018; Samocha, 2019). Furthermore, with regards to high stocking density, one of the strategies that need to be considered in order to increase the production efficiency is the use of microalgae including diatoms and green algae, as a complemented live feed in shrimp culture system (Ju et al., 2009; Samocha et al., 2015; Niu et al., 2018).

The presence of microalga community, especially diatoms, are essential and play an important role to enhance the quality of feed due to their high nutritional value and can contribute with essential amino acids and highly unsaturated fatty acids (HUFA) (Ju et al., 2009; Godoy et al., 2012; Jamali et al., 2015; Martins et al., 2016; de Abreu et al., 2019). In terms of productivity, diatoms are thought to contribute as much as $45 \%$ of the total oceanic primary production (Mann, 1999) and the diatom-dominated floc culture has been considered as a good source of nutrition that could enhance the growth of the shrimp (da Silva et al., 2013). Moreover, biomass of microalga Thalassiosira pseudonana has been considered as an essential feed for white shrimp seeding productions due to the their fatty acid, protein, carbohydrates content and large variety of minerals that can fulfill the specific nutrient requirement of Litopenaeus vannamei at the early culture stage (Van Nguyen, 2018). These studies suggest the potential benefit of providing diatoms to increase the production efficiency. Unfortunately, the growth of diatoms Thalassiosira sp. also affected by salinity and other environmental factors within the culture environment (García et al., 2012). Therefore, it is important to develop better strategy to enhance the growth of Thalassiosira sp.

Aquaritin Aqua, a commercial nano nutrients, is a unique mixture of nutrient inputs designed at nano scale targeted for sustained growth of diatoms, esp. Thalasissoria sp.. The inter nutrient ratios and sizes in Aquaritin Aqua are designed to obviate any possibility of nutrient toxicity. Sustained enhancement in diatom population provides live feed to the microscopic shrimp larvae, which develops their raptorial behavior and inherent autolysis system. The growth of diatoms deliver many benefits, including enhances the survival rate (SR), reduces feed conversion ratio (FCR) and causes significant reduction in blue green algae. Prolific photosynthesis by sustained population of diatoms also enhances the dissolved oxygen levels across the water-body that helps in cutting down aerator running hours. There is also limited information about the effect of diatoms Thalassiosira sp. to enhance the growth of Pacific white shrimp Litopenaeus vannamei. Therefore, the aim of the present study was to evaluate the extent growth of diatoms Thalassiosira sp. triggered by Aquaritin Aqua nano scale nutrients and their effect to the clarity and quality of water, growth performance of Pacific white shrimp Litopenaeus vannamei, and protein composition on the whole body of the shrimp.

\section{MATERIALS AND METHODS}

\section{Algae culture}

The pure culture of Thalassiosira sp. were obtained from Batam Dae Seng Indonesia (Batam, Riau Island province, Indonesia). Prior to stocking, diatom were held for two weeks in a $5,000 \mathrm{~m}^{2}$ acclimation trough in seawater, filled with natural seawater (29-32 g/L). This water 
fertilized once with $\mathrm{NO}_{3}, \mathrm{PO}_{4}, \mathrm{Fe}$, and other trace minerals. At start of the trial, the algae were harvested, cropped, and restocked at predetermined treatment densities.

\section{Growth trial}

This study was performed at the Batam Dae Seng Indonesia (Batam, Riau Island province, Indonesia). Post larvae of Pacific white shrimp Litopenaeus vannamei (PL8 weighing 0.03-0.05 g) were obtained from PT Maju Tambak Sumur hatchery in Kalianda, Lampung, Indonesia. At the start of the production trial, the culture ponds were prepared with the addition of Thalassiosira sp. until all ponds reach the similar density of Thalassiosira sp. $\left(10^{5}\right.$ cell $\left./ \mathrm{mL}\right)$. Then, post larvae Litopenaeus vannamei (PL 7-8) were stocked into 16 semi-indoor concrete tanks $(8 \times 8$ $\times 1 \mathrm{~m}$ ) with density of $500 \mathrm{PL} / \mathrm{m}^{2}$ in a completely randomized design.

There are four different treatments with four replications per treatment of Aquaritin Aqua (AA) nano nutrients that were diluted in water at recommended ratio of dilution of $1: 1000$ and applied in the culture system, namely: (1) 0,70 $\mathrm{mg} / \mathrm{L}$; (2) $0,525 \mathrm{mg} / \mathrm{L}$, (3) $0,35 \mathrm{mg} / \mathrm{L}$, and (4) control group or without any AA application, but included standard application of using common fertilizer (Urea and NPK fertilizers) to enhance the growth of diatom. The production period was 90 days with the addition of AA were conducted every 10 days during the culture period. The density of Thalassiosira sp. as the cultured diatom was measured using microscopic method one day prior to the addition of AA and one day after the addition of AA using hand-held water sprayer (5 L in capacity) (ACE hardware) that was calibrated to spray $20 \mathrm{~mL}$ per cycle. For the control group, the growth of diatom that was triggered by the addition of commercial organic fertilizers, the density of diatom were measured similar with the AA treatment group. Cultured tanks were filled with water with a salinity of 30-33 g/L. The primary source of mechanical aeration was with an air disc fine bubble diffuser, with one 0.5 HP paddlewheel (Minipadd ${ }^{\mathrm{TM}}$ ) per tank providing additional aeration. Water exchange was $5-10 \%$ throughout the 90 days trial.

\section{Feed management}

Shrimp in all the tanks were fed with the same diet (33-35\% crude protein, 5\% crude lipids) produced by Evergreen (Indonesia Evergreen Agriculture, Lampung Selatan) throughout the growth trial. The amount of feed used in this experiment was calculated based on the expected weight gain of $1 \mathrm{~g} /$ week, a feed conversion ratio (FCR) of 1.4 and a weekly mortality of 3\% during the grow-out period. During the trial, shrimp were fed six times per day and the daily ration was adjusted based on the percentage of body weight after sampling the shrimp on a weekly basis.

\section{Growth sampling and water quality}

Shrimp were sampled weekly throughout the production cycle using a hand net $(0.5 \mathrm{~m}$ in diameter and $1 \mathrm{~cm}$ mesh size) to collect approximately 20-30 individuals per tank. Water quality ( $\mathrm{DO}, \mathrm{pH}$, temperature, and salinity) was monitored four times per day $(06.00-07.00 \mathrm{~h}$; $14.0-15.00 \mathrm{~h} ; 17.00-18.00 \mathrm{~h}$ and $23.00-24.00$ h) using real-time water quality sensors (Aqua Troll 500, In-Situ Inc., Fort Collins, CO, USA) and managed by AquaEasy Smart Aquaculture apps (BOSCH, Singapore). Secchi disk readings were recorded once a week. Ammonia nitrogen $\left(\mathrm{NH}_{3}-\mathrm{N}\right)$ was analyzed with ultraviolet/visible spectrophotometer (PerkinElmer, Lambda XLS, USA) once a week (Table 1).

Meanwhile, nitrite nitrogen $\left(\mathrm{NO}_{2}-\mathrm{N}\right)$ and total ammonia nitrogen $\left(\mathrm{NH}_{3}-\mathrm{N}\right)$ were analyzed using HACH DR890 colorimeter (Hach Company, Love- land, CO, USA) twice a week (Table 1). At the end of the growth trial, shrimp were harvested fully, counted and batched weighed to calculate the final biomass, final weight, percentage weight gain (\%WG), FCR, survival (SR), and voluntary feed intake (VFI) as shown in Table 2.

Table 1. Overall water quality measurements during the 90 days shrimp grow-out phase of the experiment. Data are presented as mean \pm standard deviation (range).

\begin{tabular}{lcccccc}
\hline & \multicolumn{5}{c}{ Parameters } \\
\cline { 2 - 7 } Time & $\begin{array}{c}\text { Temperature } \\
\left({ }^{\circ} \mathrm{C}\right)\end{array}$ & $\begin{array}{c}\text { Dissolved oxygen } \\
(\mathrm{mg} / \mathrm{L})\end{array}$ & $\mathrm{pH}$ & $\begin{array}{c}\text { Salinity } \\
(\mathrm{g} / \mathrm{L})\end{array}$ & $\begin{array}{c}\text { Ammonia } \\
(\mathrm{mg} / \mathrm{L} \mathrm{TAN})\end{array}$ & $\begin{array}{c}\text { Nitrite } \\
(\mathrm{mg} / \mathrm{L} \mathrm{NO}-\mathrm{N})\end{array}$ \\
\hline $\mathrm{AM}$ & $27.76 \pm 0.85$ & $5.96 \pm 0.23$ & $7.81 \pm 0.09$ & $24.22 \pm 2.74$ & $0.38 \pm 0.09$ & $0.28 \pm 0.04$ \\
$\mathrm{PM}$ & $29.27 \pm 0.98$ & $5.71 \pm 0.41$ & $7.69 \pm 0.26$ & $23.60 \pm 8.51$ & \\
\hline
\end{tabular}




$$
\begin{gathered}
\text { \% WG }=\frac{\text { (average final weight }- \text { average initial weight })}{\text { (average initial weight })} \times 100 \\
\mathrm{FCR}=\frac{\text { Feed given }(\mathrm{g})}{\text { Alive weight gain }(\mathrm{g})} \\
\% \mathrm{SR}=\frac{\text { Final number of shrimp }}{\text { Initial number of shrimp }} \times 100
\end{gathered}
$$

\section{Protein composition analysis}

Upon termination of the trial, four shrimp from each tank or sixteen shrimp per treatment were randomly sampled and stored at $-60^{\circ} \mathrm{C}$ for body composition analysis. Prior to the protein analysis, dried whole shrimp were rigorously blended and chopped in a mixer according to the standard methods established by Association of Official Analytical Chemists (AOAC, 1990). Protein contents of whole shrimp body were analyzed by combustion according to the DUMAS Method (ISO 16634-1; ISO, 2008) and performed by the Bogor Agricultural University (Bogor, West Java, Indonesia)

\section{Statistical analysis}

All growth parameters were analyzed using one-way analysis of variance (ANOVA) to determine the significant differences among treatments followed by Tukey's multiple comparison tests to determine the difference between treatment means in each trial. All statistical analyses were conducted using SAS system (V9.4. SAS Institute, Cary, NC, USA).

\section{RESULTS AND DISCUSSION}

The present study demonstrates the effectiveness of Aquaritin Aquaculture (AA) contains with a mix of 11 nano-scale nutrients (minerals) and proprietary mineral compound called SN 25 to enhance the growth of diatom Thalassiosira sp. and shrimp Litopenaeus vannamei in the culture ponds. The better growth performance of shrimp also complemented with better feed utilization efficiency, not only to the formulated diet but also to the phytoplankton floc, especially diatom Thalassiosira sp. throughout the 90 days of the culture period.

Microalgae such as diatoms and green algae can grow naturally and develop in shrimp pond production system, and shrimp can get the benefit through the continuous consumption of the phytoplankton floc (Tacon et al., 2002; Shaari et al., 2011; Sotomayor et al., 2019). Our study indicated that the addition of Aquaritin Aquaculture where the production involves sequential loading of nano-adsorbates on nanoadsorbents through a unique process that allows cations and anions to be loaded on a single formulation could effectively extent the growth of Thalassiosira sp.. The growth of Thalassiosira sp. was highest in the group treated with 0,70 $\mathrm{mg} / \mathrm{L}$, followed by $0.53 \mathrm{mg} / \mathrm{L}, 0.35 \mathrm{mg} / \mathrm{L}$ and the control group. Despite all groups has similar decreasing trend, but the group of $0.70 \mathrm{mg} / \mathrm{L}$ could hold the number of Thalassiosira sp. in the ponds compared to other treatment. During the last five weeks of observations, the density

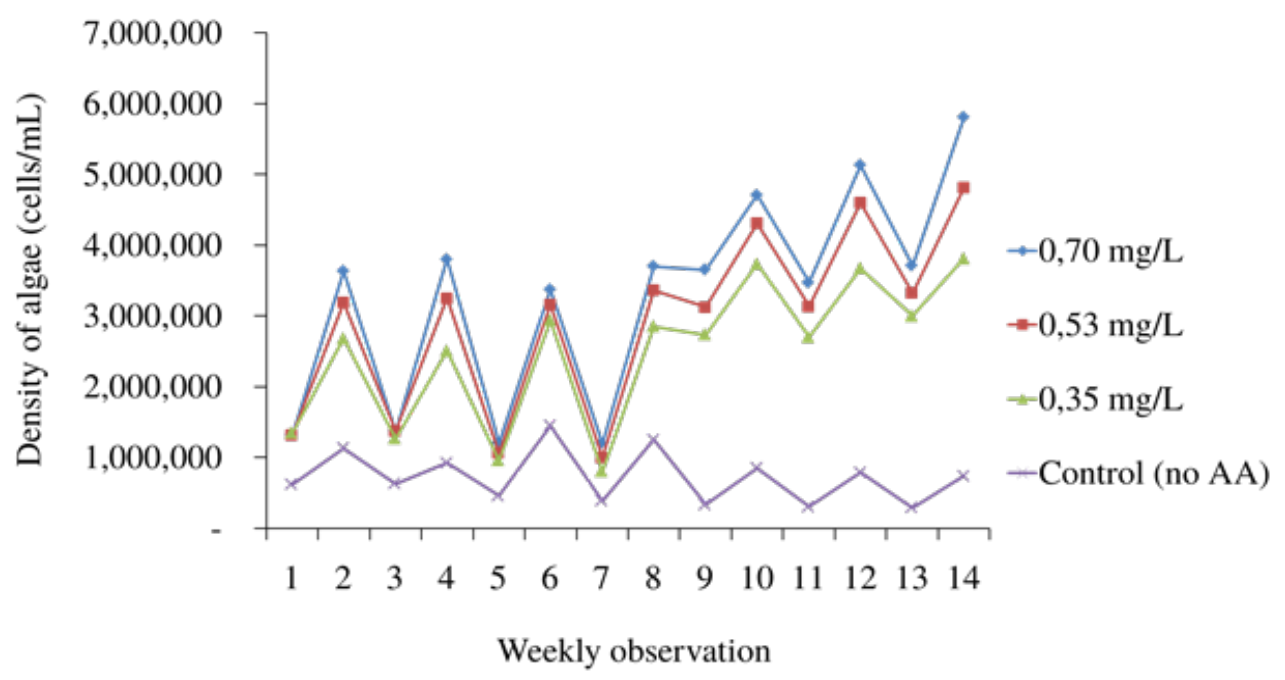

Figure 1. Cell densities profile of Thalassiosira sp. in the cultured tanks during the periods of before and after the addition of Aquaritin Aquaculture with 4 (four) different concentration, namely: (1) $0.70 \mathrm{mg} / \mathrm{L}$, (2) $0.53 \mathrm{mg} / \mathrm{L}$, (3) $0.35 \mathrm{mg} / \mathrm{L}$ and (4) control treatment 
of Thalassiosira sp. were higher than the first four weeks of the growth trial in the concrete ponds containing shrimp. This could be due to the excess of remaining feeds, feces and also the accumulation of organic materials become the substrate to support the growth of the diatom. Looking at the lower growth of diatoms in the control treatment, this could be due to the lower fixation rate of common fertilizers added into the pond.

The stocking density used in this growth trial was $500 \mathrm{PL} / \mathrm{m}^{2}$ and specified as an intensive scale of shrimp culture system (Gao et al., 2012; Primphon et al., 2016; Zulkarnain et al., 2020). In this type of culture system, applying appropriate feeding strategies are important to ensure the optimization of feed utilization, which also affect the farm productivity, FCR, growth rate, water pollution, and economic returns of the culture system (Van et al., 2017). For intensive culture system, feed input could be either applied at a standard ration to optimize growth and economic return or at restricted rations to reduce the FCR during the culture period. However, if we focus on economic returns, further optimizing the levels of feed inputs can be achieved by encourages the shrimp to utilize the natural foods (Jatobá et al., 2014; Van et al., 2017). Results of our feeding trial indicated that adding Aquaritin Aquaculture to enhance the growth of Thalassiosira sp. could also improve the biomass, final mean weight, survival, percentage weight gain and better feed utilization in terms of FCR during the culture period. Shrimp in the enhanced ponds $(0,70$ $\mathrm{mg} / \mathrm{L})$ had better final biomass $(\mathrm{kg})$, final mean weight $(\mathrm{g})$, survival (\%), weight gain $(\%)$ and lowest FCR than those in the group of $0.53 \mathrm{mg} / \mathrm{L}$, $0.35 \mathrm{mg} / \mathrm{L}$ and control treatment (Figure 3 and Table 2). Shrimp treated with $0.70 \mathrm{mg} / \mathrm{L}$ of AA had a better FCR compared to other group and this could be due to the presence of Thalassiosira sp. in sufficient number to support the growth and fulfill the nutrient requirement of shrimp $L$. vannamei.

Nutritional study in the past indicate that both $₫-6$ and $\Phi-3$ fatty acids are dietary essential for juvenile of Litopenaeus vannamei, with $\omega-3$ fatty acids promoted faster growth than $₫-3$ (Lim et al., 1997). Based on fatty acid composition analysis of three diatom species commonly used in aquaculture showed that the highest content of lipid was found in Chaetoceros gracilis, then followed by Thalassiosira sp., while the lowest was in Skeletonema costatum (Prartono et al., 2013). Still from the same report, Prartono et al. (2013) reported that the highest fatty acids methyl esters (FAME) content found in Thalassiosira sp.. was methyl palmitic $\left(\mathrm{C}_{16: 0}\right)$ that can be obtained through extraction process using chloroform and methyl palmitoleic $\left(\mathrm{C}_{16: 1}\right)$ extracted by hexane. The uses of diatoms have been reported to be beneficial algae in shrimp ponds since they could form large floc aggregates which could be ingested by shrimp (Burford, 1997; Suita et al., 2015). Study from Ju et al. (2009) indicated that adding the whole diatom or nanno-biomass to the control diet can significantly improve shrimp growth, survival and fatty acids contents in shrimp tails. This in line with our study and indicated that the enhanced diatoms in shrimp culture had a major role in improving the growth of the shrimp.

There were also significant differences in terms of water clarity $(\mathrm{m})$ during the culture period. The secchi-disk readings showed that the clarity (Figure 2) that also illustrated the density of diatoms during the culture period was lower in $0.7 \mathrm{mg} / \mathrm{L}$ group, followed by $0.53 \mathrm{mg} / \mathrm{L}, 0.35$ $\mathrm{mg} / \mathrm{L}$ and control group. The overall mean and standard deviation of morning and afternoon $\mathrm{pH}$, salinity $(\mathrm{g} / \mathrm{L})$, water temperature $\left({ }^{\circ} \mathrm{C}\right)$ and dissolved oxygen $(\mathrm{mg} / \mathrm{L})$ together with ammonia $\left(\mathrm{mg} / \mathrm{L}\right.$ TAN) and nitrite $\left(\mathrm{mg} / \mathrm{L} \mathrm{NO}_{2}-\mathrm{N}\right)$ are

Table 2. Growth performance of Pacific white shrimp Litopenaeus vannamei (mean initial weight 0.03-0.05 g) treated with Aquaritin Aquaculture for $90 \mathrm{~d}$.

\begin{tabular}{cccccc}
\hline Treatment & Final biomass $(\mathrm{kg})$ & $\begin{array}{c}\text { Final mean weight } \\
(\mathrm{g})\end{array}$ & Survival (\%) & $\mathrm{WG}^{1}(\%)$ & FCR $^{2}$ \\
\hline $0.70 \mathrm{mg} / \mathrm{L}$ & $259.00^{\mathrm{a}}$ & $10.58^{\mathrm{a}}$ & $76.54^{\mathrm{a}}$ & $35.150^{\mathrm{a}}$ & $1.35^{\mathrm{a}}$ \\
$0.53 \mathrm{mg} / \mathrm{L}$ & $248.50^{\mathrm{b}}$ & $10.34^{\mathrm{b}}$ & $75.11^{\mathrm{a}}$ & $34.359^{\mathrm{b}}$ & $1.41^{\mathrm{a}}$ \\
$0.35 \mathrm{mg} / \mathrm{L}$ & $231.50^{\mathrm{c}}$ & $10.15^{\mathrm{c}}$ & $71.27^{\mathrm{b}}$ & $33.733^{\mathrm{c}}$ & $1.51^{\mathrm{b}}$ \\
$0 \mathrm{mg} / \mathrm{L}$ & $218.00^{\mathrm{d}}$ & $9.58^{\mathrm{d}}$ & $71.11^{\mathrm{b}}$ & $31.833^{\mathrm{d}}$ & $1.61^{\mathrm{c}}$ \\
\hline
\end{tabular}

Note: ${ }^{1} \mathrm{WG}=$ Weight gain; ${ }^{2} \mathrm{FCR}=$ Feed conversion ratio. Values represent the mean of ten replicates. Results in the same columns with different superscript letter are significantly different $(\mathrm{P}<0.05)$ based on analysis of variance followed by the Tukey's multiple comparison test. 
displayed in Table 1. Based on the data, all the physical parameters are still within the acceptable range for $L$. vannamei. In addition, ammonia in the range of $0.38 \pm 0.09 \mathrm{mg}$ TAN/L and Nitrite in the range of $0.28 \pm 0.04 \mathrm{mg} / \mathrm{L} \mathrm{NO} \mathrm{NO}_{2}-\mathrm{N}$ also still within the acceptable range for Pacific white shrimp L. vannamei (Xu et al., 2013)

This data also indicated that the addition of AA do not trigger the nutrient-rich water condition within the culture system. The application of treatment ponds in this study that include the hydraulic retention times in combination with biofiltration process could also effectively minimize the possibility of serious eutrophication in the surrounding water environments. High turbid waters, as indicated by the low secchi-disk reading, are likely due to the growth of Thalassiosira sp. in the culture ponds. With respect to the present study, growth rates of Thalassiosira sp. increased in response to the increasing addition level of AA into the culture environment. The use of hand-held water sprayer in this study may help to speedup the distribution process of nano-protein and enhanced the penetration of AA to the culture environment. This study further explains due to the high reactivity of nano-nutrients, resulting in an increase and effective absorption of nutritional elements to support the growth of Thalassiosira sp.

The addition of AA to enhance the growth of Thalassiosira sp. also provides a beneficial

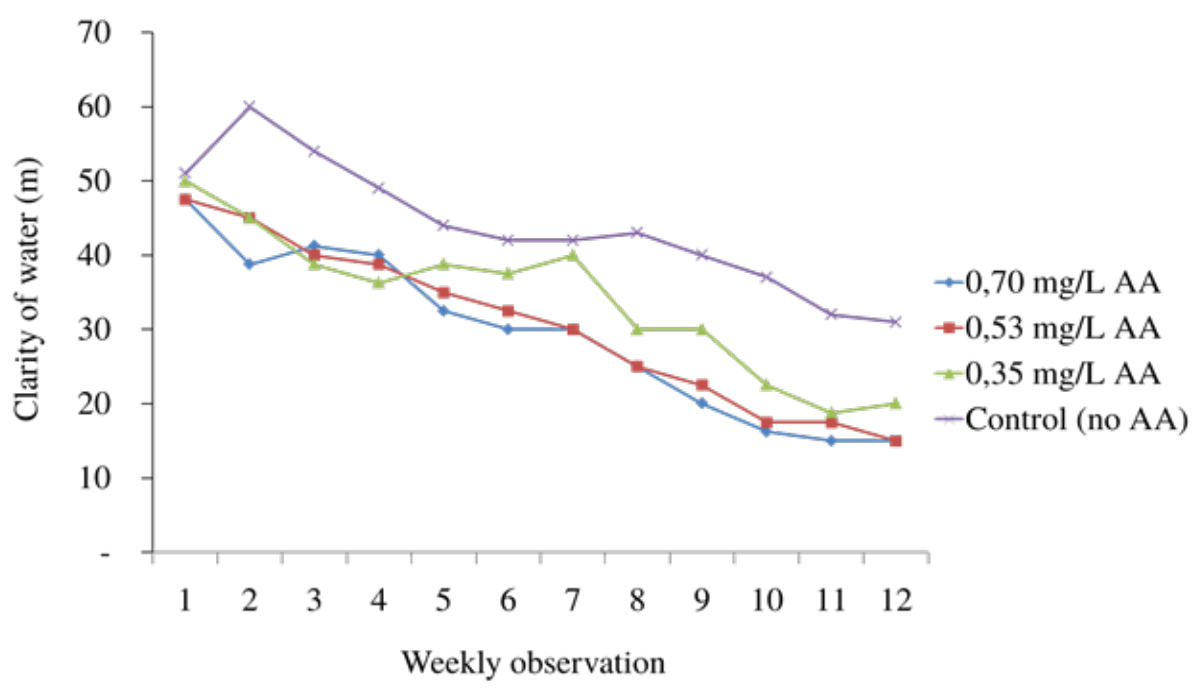

Figure 2. Profile of the clarity of water during the culture of the shrimp L. vannamei enriched with three different concentrations of Aquaritin Aquaculture and control treatment.

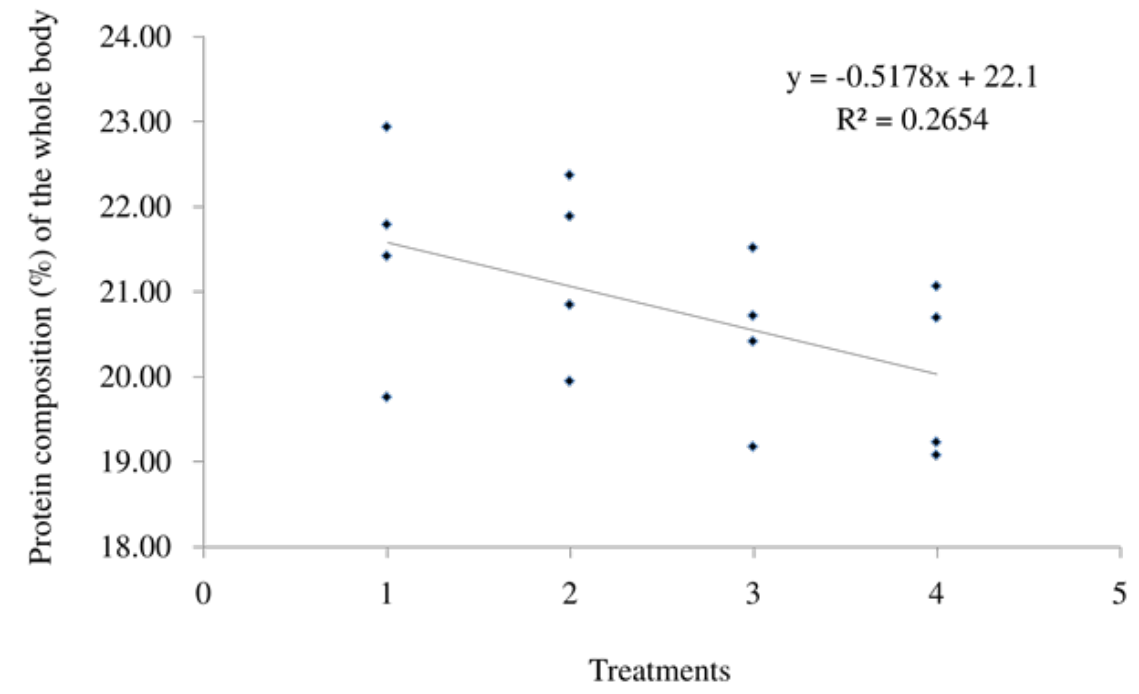

Figure 3. Protein composition (\%) in the whole body of shrimp treated with (1) $0.70 \mathrm{mg} / \mathrm{L}$, (2) $0.53 \mathrm{mg} / \mathrm{L}$, (3) 0.35 $\mathrm{mg} / \mathrm{L}$ Aquaritin Aquaculture and (4) control treatment. Values represent the mean of four replicates. 
impact to the protein composition in whole body of shrimp (Figure 3). Despite statistically, there is no significant differences were observed in the protein level in the whole-body of shrimp across all treatments. Biologically, the protein composition in the whole body of shrimp treated with $0,70 \mathrm{mg} / \mathrm{L}$ was higher compared to the group of shrimp treated with $0,53 \mathrm{mg} / \mathrm{L}, 0,35 \mathrm{mg} / \mathrm{L}$ and control group. The results of this research indicate that the use of AA to enhance the growth of Thalassiosira sp. may led to an adequate nutritional availability to fulfill the specific nutrient requirement of $L$. vannamei.

\section{CONCLUSION}

The findings from this study can be summarized in a conceptual model where the addition of Aquaritin Aquaculture (AA) could enhanced the growth of Thalassiosira sp. as the good source of fatty acid to fulfill the specific nutrient requirements of shrimp. The utilization of natural phytoplankton floc by the shrimp during the culture period can improve the growth rates and nutritional profile of the Pacific white shrimp L. vannamei. The better growth performance indicates the potential advantages of using Aquaritin Aquaculture as an effective nutrient source to develop the phytoplankton flocs in shrimp ponds and support the growth and nutritional profile of shrimp during the culture periods. In future studies, we can analyze the nutritional effects of AA to enhance the growth of other microalgae and also the growth and fatty acid composition of $L$. vannamei.

\section{ACKNOWLEDGEMENTS}

We would like to thank PT. Sinergi Samudera Biru staff in Batam Nutrition Research CenterIndonesia, special thanks to Suprianto, Hartati Sri Devi Saragih, and Muhamad Anwary for their help in feeding and sampling program. The authors would also like to extend the gratitude to those who have taken the time to critically review this manuscript as well as those who helped in supporting this research.

\section{REFERENCES}

Anh PT, Kroeze C, Bush SR, Mol AP. 2010. Water pollution by intensive brackish shrimp farming in south-east Vietnam: Causes and options for control. Agricultural Water Management 97: 872-882.
Bardera G, Owen MA, Façanha F N, AlcarazCalero JM, Sloman KA, Alexander ME. 2020. Assessing feed attractability in Pacific white shrimp Litopenaeus vannamei using an automated tracking software. Aquaculture 529: 735692.

Burford M. 1997. Phytoplankton dynamics in shrimp ponds. Aquaculture Research 28: 351-360.

da Silva KR, Wasielesky Jr W, Abreu PC. 2013. Nitrogen and phosphorus dynamics in the biofloc production of the pacific white shrimp, Litopenaeus vannamei. Journal of the World Aquaculture Society 44: 30-41.

de Abreu JL, Brito LO, de Lima PCM, Silva SMBCD, Severi W, Gálvez AO. 2019. Effects of addition of Navicula sp. (diatom) in different densities to postlarvae of shrimp Litopenaeus vannamei reared in a BFT system: Growth, survival, productivity and fatty acid profile. Aquaculture Research 50: 2231-2239.

Gao L, Shan HW, Zhang T W, Bao WY, Ma S. 2012. Effects of carbohydrate addition on Litopenaeus vannamei intensive culture in a zero-water exchange system. Aquaculture 342: 89-96.

García N, López-Elías JA, Miranda A, MartínezPorchas M, Huerta N, García A. 2012. Effect of salinity on growth and chemical composition of the diatom Thalassiosira weissflogii at three culture phases. Latin American Journal of Aquatic Research 40: 435-440.

Godoy LC, Odebrecht C, Ballester E, Martins TG, Wasielesky W. 2012. Effect of diatom supplementation during the nursery rearing of Litopenaeus vannamei (Boone, 1931) in a heterotrophic culture system. Aquaculture International 20: 559-569.

Haslun J, Correia E, Strychar K, Morris T, Samocha T. 2012. Characterization of bioflocs in a no water exchange super-intensive system for the production of food size Pacific white shrimp Litopenaeus vannamei. International Journal of Aquaculture 2: 29-39.

Jamali H, Ahmadifard N, Abdollahi D. 2015. Evaluation of growth, survival and body composition of larval white shrimp Litopenaeus vannamei fed the combination of three types of algae. International Aquatic Research 7: 115-122.

Jatobá A, da Silva BC, da Silva JS, do Nascimento Vieira F, Mouriño JLP, Seiffert WQ, Toledo TM. 2014. Protein levels for Litopenaeus vannamei in semi-intensive and biofloc systems. Aquaculture 432: 365-371. 
Jescovitch LN, Ullman C, Rhodes M, Davis DA. 2018. Effects of different feed management treatments on water quality for Pacific white shrimp Litopenaeus vannamei. Aquaculture Research 49: 526-531.

Ju ZY, Forster IP, Dominy WG. 2009. Effects of supplementing two species of marine algae or their fractions to a formulated diet on growth, survival and composition of shrimp Litopenaeus vannamei. Aquaculture 292: 237-243.

Kumar G, Engle CR. 2016. Technological advances that led to growth of shrimp, salmon, and tilapia farming. Reviews in Fisheries Science \& Aquaculture 24: 136-152.

Lee G, Suzuki A, Nam, V. H. 2019. Effect of network-based targeting on the diffusion of good aquaculture practices among shrimp producers in Vietnam. World Development 124: 104641.

Lim C, Ako H, Brown CL, Hahn K. 1997. Growth response and fatty acid composition of juvenile Penaeus vannamei fed different sources of dietary lipid. Aquaculture 151: 143-153.

Mann DG. 1999. The species concept in diatoms. Phycologia 38: 437-495.

Martins TG, Odebrecht C, Jensen LV, D'Oca MG, Wasielesky Jr W. 2016. The contribution of diatoms to bioflocs lipid content and the performance of juvenile Litopenaeus vannamei (Boone, 1931) in a BFT culture system. Aquaculture Research 47: 1315-1326.

Niu J, Xie SW, Fang HH, Xie JJ, Guo TY, Zhang YM, Liu YJ. 2018. Dietary values of macroalgae Porphyra haitanensis in Litopenaeus vannamei under normal rearing and WSSV challenge conditions: effect on growth, immune response and intestinal microbiota. Fish \& Shellfish Immunology 81: 135-149.

Prartono T, Kawaroe M, Katili V. 2013. Fatty acid composition of three diatom species Skeletonema costatum, Thalassiosira sp., and Chaetoceros gracilis. International Journal of Environment and Bioenergy 6: 28-43.

Primphon M, Chuchird N, Limsuwan C. 2016. Effect of microorganisms on production and cost-benefit analysis of intensive Pacific white shrimp Litopenaeus vannamei culture. Journal of Fisheries and Environment 40: 15-25.

Reis J, Novriadi R, Swanepoel A, Jingping G, Rhodes M, Davis DA. 2020. Optimizing feed automation: improving timer-feeders and on demand systems in semi-intensive pond culture of shrimp Litopenaeus vannamei. Aquaculture 519: 734759.

Samerwong P, Bush SR, Oosterveer P. 2018. Implications of multiple national certification standards for Thai shrimp aquaculture. Aquaculture 493: 319-327.

Samocha TM, Fricker J, Ali AM, Shpigel M, Neori A. 2015. Growth and nutrient uptake of the macroalga Gracilaria tikvahiae cultured with the shrimp Litopenaeus vannamei in an integrated multi-trophic aquaculture (IMTA) system. Aquaculture 446: 263-271.

Samocha TM. 2019. Sustainable biofloc systems for marine shrimp. Academic Press.

Shaari AL, Surif M, Abd F. Latiff FA, Omar WMW, Ahma MN. 2011. Monitoring of water quality and microalgae species composition of Penaeus monodon ponds in Pulau Pinang, Malaysia. Tropical Life Sciences Research 22: 51-69.

Soares R, Peixoto S, Galkanda-Arachchige HS, Davis DA. 2021. Growth performance and acoustic feeding behavior of two size classes of Litopenaeus vannamei fed pelleted and extruded diets. Aquaculture International 29: 399-415.

Sotomayor MA, Reyes JK, Restrepo L, Domínguez-Borbor C, Maldonado M, Bayot B. 2019. Efficacy assessment of commercially available natural products and antibiotics, commonly used for mitigation of pathogenic Vibrio outbreaks in Ecuadorian Penaeus (Litopenaeus) vannamei hatcheries. PloS one 14: e0210478.

Suita SM, Ballester ELC, Abreu PCOVD, Wasielesky Junior W. 2015. Dextrose as carbon source in the culture of Litopenaeus vannamei (Boone, 1931) in a zero exchange system. Latin American Journal of Aquatic Research 43: 526-522

Suantika G, Lumbantoruan G, Muhammad H, Azizah FFN, Aditiawati P. 2015. Performance of zero water discharge (ZWD) system with nitrifying bacteria and microalgae Chaetoceros calcitrans components in super intensive white shrimp Litopenaeus vannamei culture. Journal of Aquaculture Research and Development 6: 359.

Tacon AGJ, Cody JJ, Conquest LD, Divakaran S, Forster IP, Decamp OE. 2002. Effect of culture system on the nutrition and growth performance of Pacific white shrimp Litopenaeus vannamei (Boone) fed different diets. Aquaculture Nutrition 8: 121-137. 
Van TPTH, Rhodes MA, Zhou Y, Davis DA. 2017. Feed management for Pacific white shrimp Litopenaeus vannamei under semi-intensive conditions in tanks and ponds. Aquaculture Research 48: 5346-5355.

Van Nguyen C. 2018. Fatty acid profile and nutrition values of microalgae Thalassiosira pseudonana commonly used in white shrimp Litopenaeus vannamei culturing. Vietnam Journal of Science and Technology 56: 138.

Xu WJ, Pan LQ, Sun XH, Huang J. 2013. Effects of bioflocs on water quality, and survival, growth and digestive enzyme activities of Litopenaeus vannamei (Boone) in zero water exchange culture tanks. Aquaculture Research 44: 1093-1102.

Zulkarnain R, Adiyana K, Waryanto, Nugroho H, Nugraha B, Thesiana L, Supriyono E. 2020. Selection of intensive shrimp farming technology for small farmers with analytical hierarchy process: a case for whiteleg shrimp Litopenaeus vannamei. IOP Conference Series: Earth and Environmental Science 404. IOP Publishing. p. 12-17 